\title{
PENERAPAN GREEN CONSTRUCTION PADA PROYEK PEMBANGUNAN TOD MAHATA MARGONDA
}

\author{
Muthia Utari ${ }^{1}$, Afrizal Nursin ${ }^{2}$ \\ 1,2, Jurusan Teknik Sipil, Politeknik Negeri Jakarta, Jl. Prof. DR. G.A. Siwabessy, \\ Kukusan, Kecamatan Beji, Kota Depok, Jawa Barat 16424. \\ e-mail:muthia.utari.ts16@mhsw.pnj.ac.id,nursin_afrizal@yahoo.com.sg
}

\begin{abstract}
Environmental damage and global warming has become an issue in the world. Developments in the construction project has a large influence in environmental change on the surface of the earth. Construction activities start from the constructing stage to the operating stage. Green construction is one part of the sustainable development that is required to participate in environmental sustainability. With this background, the author agreed to explain the criteria, stages of difficulty and obstacles in implementing Green Construction. Data collected by questionnaire method and data analysis using SPSS Statistics 26. The results of this study obtained the value of the Green Construction criteria that applied is waste project variables with an average value of 3,748 and the lowest is site project variables with average 3,198. The most dominant factor of difficulty in applying Green Construction is the water usage variable with an average value of 3,283 and the lowest difficulty in applying is the energy variable with an average of 2,817. The most challenging obstacle factor in implementing Green Construction is the cost factor with an average value of 4.00 and the lowest obstacle is the efficient design variable with an average of 2.96. Thus, from the results of this study is expected that the contractor can help more actively in improving the implementation of Green Construction in this construction project.
\end{abstract}

Keywords: Green Construction; Obstacles; Level of difficulty; Level of application; Construction project.

\begin{abstract}
ABSTRAK
Kerusakan lingkungan dan pemanasan global sudah menjadi isu di masyarakat dunia. Perkembangan pada proyek konstruksi dianggap sangat memiliki peran besar terhadap perubahan lingkungan di permukaan bumi. Dimulai dari tahap konstruksi hingga tahap operasional kegiatan konstruksi. Green construction merupakan salah satu bagian dari pembangunan yang berkelanjutan diharapkan mampu ikut menjaga kelestarian lingkungan. Dengan latar belakang tersebut, penulis bermaksud untuk menjabarkan kriteria, tingkat kesulitan dan hambatan dalam menerapkan Green Construction. Metode pengumpulan data menggunakan kuesioner terhadap responden di proyek dan analisis data menggunakan SPSS Statistics 26. Hasil penelitian tersebut diperoleh nilai faktor kriteria Green Construction yang paling diterapkan yaitu pada variabel limbah proyek dengan nilai rata-rata sebesar 3.748 dan yang paling rendah penerapannya yaitu variabel lapangan dengan rata-rata 3.198. Faktor tingkat kesulitan menerapakan Green Construction yang paling mendominasi yaitu variabel penggunaan air dengan nilai rata-rata sebesar 3.283 dan yang paling rendah kesulitan penerapannya yaitu variabel energi dengan rata-rata 2.817. Faktor hambatan dalam menerapkan Green Construction yang paling mendominasi yaitu faktor modal dengan nilai rata-rata sebesar 4.00 dan yang paling rendah hambatannya yaitu variabel pembuatan design yang efesien dengan rata-rata 2.96. Dengan demikian, dari hasil penelitian ini diharapkan kontraktor dapat berperan lebih aktif dalam meningkatkan penerapan Green Construction pada pelaksanaan proyek konstruksi ini.
\end{abstract}

Kata kunci: Green Construction; Hambatan; Tingkat kesulitan; Tingkat penerapan; Proyek konstruksi. 


\section{PENDAHULUAN}

Proses konstruksi pembangunan gedung yang memanfaatkan sumber daya alam sebagai bahan bakunya yang berkemungkinan turut andil dalam menciptakan pada kerusakan lingkungan dari pemanfaatan sumber daya alam yang jumlahnya semakin terbatas ini, serta terdapat dampak yang timbul dari penggunaan fasilitas bangunan dan pemilihan material bangunan yang terkait dengan peningkatannya suhu di bumi. [1]

Indonesia sudah menyatakan komitmennya kepada dokumen Nationally Determined Contribution bahwa Indonesia dapat menurunkan emisi gas rumah kaca dengan menetapkan target $29 \%$ untuk unconditional dan target $41 \%$ unutk conditional di tahun 2030. Secara nasional, Indonesia menargetkan penurusan emisi yang sangat tinggi di tahun 2030 dengan target penurunan emisi sebesar 2,869 million metric ton CO2e. [2]

Dalam menerapkan kondisi yang ramah lingkungan diperlukan kriteria yang dapat digunakan sebagai acuan dalam proses penerapannya. Green construction menjadi salah satu bagian dari proses pembangunan berkelanjutan yang diharapkan dapat menjaga kelestarian lingkungan.

Green Construction sebuah dari perencanaan dan pelaksanaan proses konstruksi yang didasarkan pada sebuah dokumen kontrak untuk meminimalkan dampak negatif yang muncul pada proses konstruksi terhadap lingkungan, tujuan tersebut diterapkan agar terjadi keseimbangan antara kemampuan lingkungan dengan kebutuhan hidup manusia untuk generasi sekarang dan mendatang. [3], [4]

Perumusan masalah penelitian ini antara lain: (a) Bagaimana penerapan
Green construction pada proyek TOD

(Transit Oriented Development) Mahata Margonda? (b) Kriteria manakah yang paling menentukan dalam menerapkan Green construction dan tingkat kesulitan yang terjadi dalam menerapkan pada proyek TOD (Transit Oriented Development) Mahata Margonda? (c) Apa faktor yang paling menghambat untuk menerapkan Green construction pada proyek TOD (Transit Oriented Development) Mahata Margonda?

Adapun tujuan dari penelitian ini yaitu: (a) Mengetahui bagimana pelaksanaan penerapan Green construction pada proyek TOD Mahata Margonda, (b) Mengetahui manakah kriteria yang paling menentukan dalam menerapkan Green construction dan tingkat kesulitan dalam penerapannya pada proyek TOD Mahata Margonda dan (c) Mengetahui faktor hambatan yang terjadi disaat menerapkan Green construction pada Proyek Mahata Margonda

Di Indonesia upaya penerapan Green construction sudah mulai dilakukan, antara lain oleh kontraktor nasional P.T. Pembangunan Perumahan (PP). [5] [6] Green Contractor Assesment Sheet merupakan salah satu instrument yang digunakan untuk menilai Green Construction yang mencakup hal-hal sebagai berikut: (a) Tepat guna lahan, (b) Efisiensi dan konservasi energi, (c) Konservasi air, (d) Manajemen lingkungan proyek konstruksi, (d) Sumber dan siklus material, (e) Kesehatan dan kenyamanan di dalam lokasi proyek konstruksi. (f) LRB (Lubang Resapan Biopori).[7], [8], [9] Menurut PT. Pembangunan Perumahan (PP) manfaat dari Green Construction untuk sebuah proyek konstruksi ada 3 (tiga), yaitu: (a) Manfaat Lingkungan, (b) Manfaat Ekonomi dan (c) Manfaat Sosial. [10], [11] 


\section{METODE PENELITIAN}

Penelitian ini dimulai dari bulan Mei 2020 - Juni 2020. Proyek Pembangunan TOD Mahata Margonda ini berlokasi di Jl. Margonda Raya No 367 Kemiri Muka, Kota Depok, Jawa Barat.

Pengumpulan data yang dilakukan menggunakan data proyek, dan penyebaran kuesioner. Responden dari penelitian ini adalah pihak kontraktor sebanyak 26 orang.

Berikut adalah gambar diagram alir penelitian.

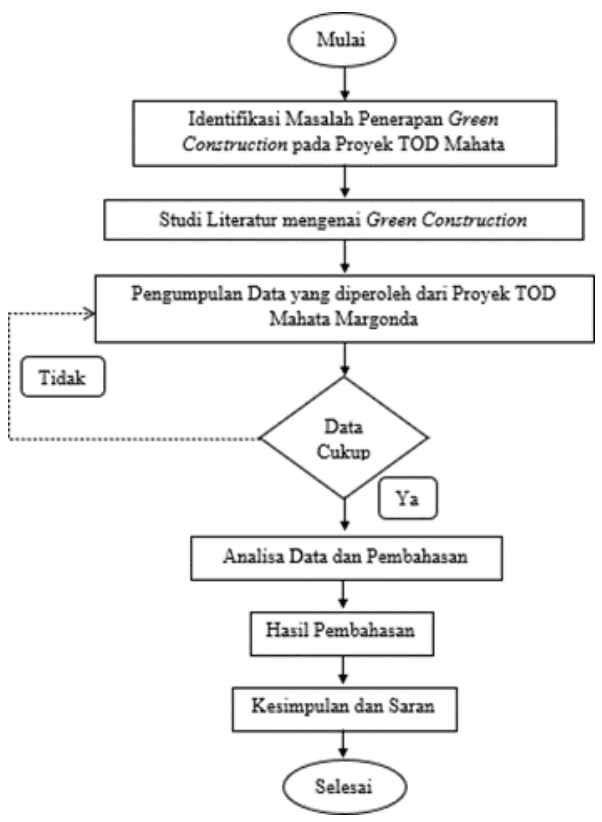

Gambar 1. Diagram Alir Penelitian

Tahapan penelitian diawali dengan mengidentifikasi masalah terkait penerapan Green Construction pada proyek pembangunan TOD Mahata Margonda, lalu dilakukan studi literatur, kemudian melakukan pengumpulan data berupa penyebaran kuesioner. Setelah data yang dikumpulkan cukup, dilakukan analisa data dengan menggunakan SPSS Statistics 26. Hasil perhitungan dijadikan pembahasan dan dilakukan penarikan kesimpulan.

\section{Metode Angket Kuisioner}

Dalam metode ini, penulis melakukan penyebaran angket kuisioner kepada responden yang berisi pertanyaanpertanyaan berkaitan dengan tingkat kriteria dan kesulitan Green Construction beserta dengan faktor hambatan yang terjadi saat melaksanakan Green Construction serta pengisiannya menggunakan skala likers.

\section{SPSS (Statistical Product and Service Solution)}

SPSS (Statistical Product and Service Solution) merupakan salah satu software statistik yang bertujuan untuk memproses sebuah data statistik secara tepat dan cepat. Program SPSS ini sangat banyak digunakan sebagai riset pasar pengendalian dan perbaikan mutu serta riset-riset sains. SPSS yang digunakan oleh penulis yaitu SPSS Statistic 26. [12]

Penelitian tersebut menggunakan statistik deskriptif yang yang bertujuan untuk mencari rata-rata (mean), standar deviasi, minimum, dan maksimum. Umumnya statistik deskriptif ini digunakan oleh peneliti-peneliti untuk memberikan suatu gambaran mengenai karakteristik variabel penelitian yang utama dan data. [13]

Penelitian ini memakai uji validitas, reabilitas, normalitas, regresi linear berganda, uji hipotesis (uji t dan F) serta uji R (determinasi). [13]

\section{HASIL dan PEMBAHASAN}

Hasil ini doperoleh dari pengolahan data dengan menggunakan SPSS Statistics 26 tingkat kriteria, tingkat kesulitan serta hambatan penerapan Green Construction, maka didapatkan hasil sebagai berikut. 


\section{Kriteria Penerapan Lapangan (Site Project)}

Tabel 1. Statistik Deskriptif Kriteria Variabel Lapangan (Site Project)

\begin{tabular}{llrrrrr}
\hline \multicolumn{7}{c}{ Descriptive Statistics } \\
& N & \multicolumn{7}{c}{ Minimum } & Maximum & Sum & Mean & Std. Deviation \\
\hline X1 & 26 & 3 & 5 & 98 & 3.77 & .587 \\
X2 & 26 & 3 & 5 & 108 & 4.15 & .613 \\
X3 & 26 & 2 & 5 & 83 & 3.19 & .939 \\
X4 & 26 & 2 & 3 & 69 & 2.65 & .485 \\
X5 & 26 & 2 & 4 & 89 & 3.42 & .578 \\
X6 & 26 & 3 & 4 & 99 & 3.81 & .402 \\
X7 & 26 & 1 & 3 & 56 & 2.15 & .613 \\
X8 & 26 & 2 & 5 & 96 & 3.69 & .679 \\
X9 & 26 & 3 & 4 & 97 & 3.73 & .452 \\
X10 & 26 & 1 & 2 & 37 & 1.42 & .504 \\
Valid N (listwise) & 26 & & & & & \\
\hline
\end{tabular}

Tabel 1 merupakan hasil nilai dari kriteria penerapan lapangan dengan nilai minimum sebesar 3 dan maksimum sebesar 5. Penerapan X2 yang berarti pengelolaan erosi tanah merupakan kriteria penerapan lapangan yang paling disetujui oleh responden dengan jumlah terbanyak sebesar 108 dan rata-rata sebesar 4.15.

\section{Kriteria Penerapan Energi}

Tabel 2. Statistik Deskriptif Kriteria Variabel Energi

\begin{tabular}{lrrrrrr}
\hline \multicolumn{7}{c}{ Descriptive Statistics } \\
& N & \multicolumn{1}{c}{ Minimum } & Maximum & Sum & Mean & Std. Deviation \\
\hline X11 & 26 & 1 & 4 & 68 & 2.62 & .852 \\
X12 & 26 & 2 & 5 & 95 & 3.65 & .892 \\
X13 & 26 & 2 & 4 & 72 & 2.77 & .652 \\
X14 & 26 & 3 & 5 & 97 & 3.73 & .667 \\
X15 & 26 & 3 & 5 & 97 & 3.73 & .533 \\
X16 & 26 & 3 & 5 & 107 & 4.12 & .653 \\
X17 & 26 & 2 & 4 & 84 & 3.23 & .652 \\
X18 & 26 & 2 & 4 & 87 & 3.35 & .629 \\
Valid N (listwise) & 26 & & & & & \\
\hline
\end{tabular}

Tabel 2 merupakan hasil nilai dari kriteria penerapan energi dengan nilai minimum sebesar 3 dan maksimum sebesar 5. Penerapan X16 yang berarti zonasi tempat tinggal karyawan atau pekerja merupakan kriteria penerapan energi yang paling disetujui oleh responden dengan jumlah terbanyak sebesar 107 dan rata-rata sebesar 4.12.
Kriteria Penerapan Emisi Gas Buang

Tabel 3. Statistik Deskriptif Kriteria Variabel Emisi Gas Buangan

\begin{tabular}{lrrrrrr}
\hline \multicolumn{7}{c}{ Descriptive Statistics } \\
& N & Minimum & Maximum & Sum & Mean & Std. Deviation \\
\hline X19 & 26 & 3 & 5 & 102 & 3.92 & .628 \\
X20 & 26 & 2 & 4 & 68 & 2.62 & .752 \\
X21 & 26 & 3 & 5 & 94 & 3.62 & .637 \\
X22 & 26 & 3 & 5 & 100 & 3.85 & .464 \\
X23 & 26 & 3 & 4 & 99 & 3.81 & .402 \\
X24 & 26 & 1 & 3 & 60 & 2.31 & .618 \\
X25 & 26 & 3 & 4 & 94 & 3.62 & .496 \\
Valid N (listwise) & 26 & & & & & \\
\hline
\end{tabular}

Tabel 3 merupakan hasil nilai dari kriteria penerapan Emisi gas buangan dengan nilai minimum sebesar 3 dan maksimum sebesar 5. Penerapan X19 yang berarti pemanfaatan material lokal (dalam negeri) merupakan kriteria penerapan emisi gas buangan yang paling disetujui oleh responden dengan jumlah terbanyak sebesar 102 dan ratarata sebesar 3.92.

\section{Kriteria Penerapan Limbah Proyek}

Tabel 4. Statistik Deskriptif Kriteria Variabel Limbah Proyek

\begin{tabular}{lrrrrrr}
\hline \multicolumn{7}{c}{ Descriptive Statistics } \\
& N & Minimum & Maximum & Sum & Mean & Std. Deviation \\
\hline X26 & 26 & 3 & 5 & 107 & 4.12 & .711 \\
X27 & 26 & 3 & 4 & 99 & 3.81 & .402 \\
X28 & 26 & 3 & 4 & 98 & 3.77 & .430 \\
X29 & 26 & 3 & 4 & 94 & 3.62 & .496 \\
X30 & 26 & 3 & 4 & 89 & 3.42 & .504 \\
Valid N (listwise) & 26 & & & & & \\
\hline
\end{tabular}

Tabel 4 merupakan hasil nilai dari kriteria penerapan limbah proyek dengan nilai minimum sebesar 3 dan maksimum sebesar 5. Penerapan X26 yang berarti pengelolaan sampah proyek (organik, non-organik dan B3) merupakan kriteria penerapan limbah proyek yang paling disetujui oleh responden dengan jumlah terbanyak sebesar 107 dan rata-rata sebesar 4.12. 
Kriteria Penerapan Penggunaan Air

Tabel 5. Statistik Deskriptif Kriteria Variabel Penggunaan Air

\begin{tabular}{lrrrrrr}
\hline \multicolumn{7}{c}{ Descriptive Statistics } \\
& $N$ & Minimum & Maximum & Sum & Mean & Std. Deviation \\
\hline X31 & 26 & 2 & 3 & 71 & 2.73 & .452 \\
X32 & 26 & 3 & 4 & 91 & 3.50 & .510 \\
X33 & 26 & 3 & 5 & 100 & 3.85 & .543 \\
X34 & 26 & 2 & 4 & 92 & 3.54 & .706 \\
X35 & 26 & 2 & 4 & 78 & 3.00 & .693 \\
X36 & 26 & 2 & 4 & 92 & 3.54 & .582 \\
Valid N (listwise) & 26 & & & & & \\
\hline
\end{tabular}

Tabel 5 merupakan hasil nilai dari kriteria penerapan penggunaan air dengan nilai minimum sebesar 3 dan maksimum sebesar 5. Penerapan X33 yang berarti penghematan penggunaan air oleh pekerja domestik merupakan kriteria penerapan penggunaan air yang paling disetujui oleh responden dengan jumlah terbanyak sebesar 100 dan ratarata sebesar 3.85.

\section{Kriteria Penerapan Material dan Sumber Daya}

Tabel 6. Statistik Deskriptif Kriteria Variabel Material dan Sumber Daya

\begin{tabular}{lrrrrrr}
\hline \multicolumn{7}{c}{ Descriptive Statistics } \\
& N & \multicolumn{7}{c}{ Minimum } & Maximum & Sum & Mean & Std. Deviation \\
\hline X37 & 26 & 3 & 5 & 101 & 3.88 & .516 \\
X38 & 26 & 2 & 4 & 88 & 3.38 & .752 \\
X39 & 26 & 3 & 4 & 86 & 3.31 & .471 \\
X40 & 26 & 3 & 5 & 99 & 3.81 & .491 \\
X41 & 26 & 3 & 5 & 109 & 4.19 & .491 \\
X42 & 26 & 4 & 5 & 114 & 4.38 & .496 \\
X43 & 26 & 3 & 5 & 97 & 3.73 & .724 \\
X44 & 26 & 2 & 3 & 69 & 2.65 & .485 \\
Valid N (listwise) & 26 & & & & & \\
\hline
\end{tabular}

Tabel 6 merupakan hasil nilai dari kriteria penerapan material dan sumber daya dengan nilai minimum sebesar 3 dan maksimum sebesar 5. Penerapan X42 yang berarti pemakaian bahan kantor temporary secara berulang merupakan kriteria penerapan material dan sumber daya yang paling disetujui oleh responden dengan jumlah terbanyak sebesar 107 dan rata-rata sebesar 4.12.

Tingkat Kesulitan Kriteria Penerapan
Pada Lapangan (Site Project)

Tabel 7. Statistik Deskriptif Tingkat Kesulitan Variabel Lapangan

\begin{tabular}{lllllll}
\hline \multicolumn{7}{c}{ Descriptive Statistics } \\
Z1 & \multicolumn{7}{c}{ Minimum } & Maximum & Sum & Mean & Std. Deviation \\
\hline Z2 & 26 & 3 & 4 & 92 & 3.54 & .508 \\
Z3 & 26 & 2 & 4 & 94 & 3.62 & .637 \\
Z4 & 26 & 2 & 5 & 91 & 3.50 & .949 \\
Z5 & 26 & 2 & 4 & 77 & 2.96 & .720 \\
Z6 & 26 & 3 & 5 & 105 & 4.04 & .599 \\
Z7 & 26 & 3 & 4 & 87 & 3.35 & .485 \\
Z8 & 26 & 2 & 5 & 86 & 3.31 & .788 \\
Z9 & 26 & 2 & 4 & 66 & 2.54 & .761 \\
Z10 & 26 & 1 & 3 & 54 & 2.08 & .688 \\
Valid N (listwise) & 26 & 3 & 5 & 91 & 3.50 & .583 \\
\hline
\end{tabular}

Tabel 7 merupakan hasil nilai dari tingkat kesulitan penerapan pada lapangan (site project) dengan nilai minimum sebesar 3 dan maksimum sebesar 5. Penerapan Z5 yang berarti pencegahan sedimentasi merupakan tingkat kesulitan penerapan pada lapangan (site project) yang paling sulit diterapkan oleh responden dengan jumlah terbanyak sebesar 105 dan ratarata sebesar 4.04.

\section{Tingkat Kesulitan Kriteria Penerapan Energi}

Tabel 8. Statistik Deskriptif Tingkat Kesulitan Variabel Energi

\begin{tabular}{lrrrrrr}
\hline \multicolumn{7}{c}{ Descriptive Statistics } \\
& N & \multicolumn{1}{c}{ Minimum } & Maximum & Sum & Mean & Std. Deviation \\
\hline Z11 & 26 & 2 & 5 & 91 & 3.50 & .762 \\
Z12 & 26 & 1 & 4 & 65 & 2.50 & .860 \\
Z13 & 26 & 2 & 4 & 86 & 3.31 & .618 \\
Z14 & 26 & 1 & 4 & 76 & 2.92 & 1.017 \\
Z15 & 26 & 1 & 4 & 58 & 2.23 & .815 \\
Z16 & 26 & 2 & 4 & 78 & 3.00 & .632 \\
Z17 & 26 & 2 & 3 & 67 & 2.58 & .504 \\
Z18 & 26 & 2 & 3 & 65 & 2.50 & .510 \\
Valid N (listwise) & 26 & & & & & \\
\hline
\end{tabular}

Tabel 8 merupakan hasil nilai dari tingkat kesulitan penerapan pada energi dengan nilai minimum sebesar 2 dan maksimum sebesar 5. Penerapan Z11 yang berarti pengaturan jam operasi AC merupakan tingkat kesulitan penerapan pada energi yang paling sulit diterapkan oleh responden dengan jumlah terbanyak sebesar 91 dan rata-rata sebesar 3.50. 


\section{Tingkat Kesulitan Kriteria Penerapan Emisi Gas Buang}

Tabel 9. Statistik Deskriptif Tingkat Kesulitan Variabel Emisi Gas Buangan

\begin{tabular}{lrrrrrr}
\hline \multicolumn{7}{c}{ Descriptive Statistics } \\
& N & Minimum & Maximum & Sum & Mean & Std. Deviation \\
\hline Z19 & 26 & 2 & 4 & 83 & 3.19 & .749 \\
Z20 & 26 & 3 & 5 & 100 & 3.85 & .613 \\
Z21 & 26 & 1 & 3 & 62 & 2.38 & .637 \\
Z22 & 26 & 2 & 3 & 60 & 2.31 & .471 \\
Z23 & 26 & 2 & 4 & 80 & 3.08 & .744 \\
Z24 & 26 & 3 & 5 & 101 & 3.88 & .588 \\
Z25 & 26 & 2 & 3 & 65 & 2.50 & .510 \\
Valid N (listwise) & 26 & & & & & \\
\hline
\end{tabular}

Tabel 9 merupakan hasil nilai dari tingkat kesulitan penerapan pada emisi gas buangan dengan nilai minimum sebesar 3 dan maksimum sebesar 5 . Penerapan Z24 yang berarti pemilihan bahan bakar biodesel merupakan tingkat kesulitan penerapan pada emisi gas buangan yang paling sulit diterapkan oleh responden dengan jumlah terbanyak sebesar 101 dan rata-rata sebesar 3.88.

\section{Tingkat Kesulitan Kriteria Penerapan Limbah Proyek}

Tabel 10. Statistik Deskriptif Tingkat Kesulitan Variabel Limbah Proyek

\begin{tabular}{|c|c|c|c|c|c|c|}
\hline \multicolumn{7}{|c|}{ Descriptive Statistics } \\
\hline & $\mathrm{N}$ & Minimum & Maximum & Sum & Mean & Std. Deviation \\
\hline Z26 & 26 & 1 & 3 & 55 & 2.12 & .711 \\
\hline Z27 & 26 & 3 & 4 & 90 & 3.46 & .508 \\
\hline Z28 & 26 & 2 & 3 & 72 & 2.77 & .430 \\
\hline Z29 & 26 & 3 & 4 & 92 & 3.54 & .508 \\
\hline $\mathrm{Z} 30$ & 26 & 2 & 4 & 82 & 3.15 & .464 \\
\hline Valid N (listwise) & 26 & & & & & \\
\hline
\end{tabular}

Tabel 10 merupakan hasil nilai dari tingkat kesulitan penerapan pada limbah proyek dengan nilai minimum sebesar 3 dan maksimum sebesar 4. Penerapan Z29 yang berarti perencanaan pengurangan limbah besi merupakan tingkat kesulitan penerapan pada limbah cair yang paling sulit diterapkan oleh responden dengan jumlah terbanyak sebesar 92 dan rata-rata sebesar 3.54.

\section{Tingkat Kesulitan Kriteria Penerapan Penggunaan Air}

Tabel 11. Statistik Deskriptif Tingkat Kesulitan Variabel Penggunaan Air

\begin{tabular}{lllllll}
\hline \multicolumn{7}{c}{ Descriptive Statistics } \\
& N & Minimum & Maximum & Sum & Mean & Std. Deviation \\
\hline Z31 & 26 & 3 & 4 & 93 & 3.58 & .504 \\
Z32 & 26 & 2 & 4 & 89 & 3.42 & .809 \\
Z33 & 26 & 2 & 4 & 79 & 3.04 & .662 \\
Z34 & 26 & 3 & 4 & 94 & 3.62 & .496 \\
Z35 & 26 & 2 & 4 & 68 & 2.62 & .571 \\
Z36 & 26 & 2 & 4 & 89 & 3.42 & .578 \\
Valid N (listwise) & 26 & & & & & \\
\hline
\end{tabular}

Tabel 12 merupakan hasil nilai dari tingkat kesulitan penerapan pada penggunaan air dengan nilai minimum sebesar 3 dan maksimum sebesar 4 . Penerapan Z34 yang berarti pengelolaan limbah cair merupakan tingkat kesulitan penerapan pada penggunaan air yang paling sulit diterapkan oleh responden dengan jumlah terbanyak sebesar 94 dan rata-rata sebesar 3.62.

\section{Tingkat Kesulitan Kriteria Penerapan Material dan Sumber Daya}

Tabel 13. Statistik Deskriptif Tingkat Kesulitan Variabel Material dan Sumber Daya

\begin{tabular}{|c|c|c|c|c|c|c|}
\hline \multicolumn{7}{|c|}{ Descriptive Statistics } \\
\hline & $\mathrm{N}$ & Minimum & Maximum & Sum & Mean & Std. Deviation \\
\hline Z37 & 26 & 2 & 4 & 90 & 3.46 & .706 \\
\hline Z38 & 26 & 4 & 5 & 113 & 4.35 & .485 \\
\hline Z39 & 26 & 2 & 4 & 80 & 3.08 & .688 \\
\hline $\mathrm{Z} 40$ & 26 & 2 & 3 & 60 & 2.31 & .471 \\
\hline Z41 & 26 & 3 & 4 & 97 & 3.73 & .452 \\
\hline Z42 & 26 & 2 & 3 & 62 & 2.38 & .496 \\
\hline Z43 & 26 & 1 & 3 & 59 & 2.27 & .533 \\
\hline Z44 & 26 & 2 & 4 & 88 & 3.38 & .571 \\
\hline Valid N (listwise) & 26 & & & & & \\
\hline
\end{tabular}

Tabel 13 merupakan hasil nilai dari tingkat kesulitan penerapan pada penggunaan air dengan nilai minimum sebesar 4 dan maksimum sebesar 5 . Penerapan Z38 yang berarti pemakaian material yang bisa didaur ulang merupakan tingkat kesulitan penerapan pada material dan sumber daya yang paling sulit diterapkan oleh responden dengan jumlah terbanyak sebesar 113 dan rata-rata sebesar 4.35. 
Pada gambar 2 di lampiran, menunjukkan grafik dari hasil keseluruhan analisa tingkat kriteria dan tingkat kesulitan dengan pengolahan data menggunakan SPSS Statistics 26.

\section{Hambatan Dalam Penerapan Green Construction}

Tabel 13. Statistik Deskriptif Hambatan Dalam Penerapan Green Construction

\begin{tabular}{|c|c|c|c|c|c|c|}
\hline \multicolumn{7}{|c|}{ Descriptive Statistics } \\
\hline & $\mathrm{N}$ & Minimum & Maximum & Sum & Mean & Std. Deviation \\
\hline Y1 & 26 & 3 & 5 & 104 & 4.00 & .632 \\
\hline Y2 & 26 & 2 & 4 & 77 & 2.96 & .720 \\
\hline Y3 & 26 & 2 & 5 & 98 & 3.77 & .815 \\
\hline Y4 & 26 & 2 & 4 & 84 & 3.23 & .652 \\
\hline Y5 & 26 & 3 & 5 & 100 & 3.85 & .732 \\
\hline Valid N (listwise) & 26 & & & & & \\
\hline
\end{tabular}

Tabel 13 merupakan hasil dari hambatan penerapan Green Construction dengan keterangan Y1 yaitu modal atau biaya, Y2 yaitu pembuatan design yang efesien, Y3 yaitu pemilihan material atau bahan baku yang ramah lingkungan, Y4 yaitu peraturan pemerintah dalam menerapkan Green Construction dan Y5 yaitu kesadaran masyarakat akan pentingnya Green Construction. [14], [15]

Modal atau biaya mempunyai nilai minimum sebesar 3 dan maksimum sebesar 5, serta jumlah sebesar 104 dan rata-rata sebesar 4.00

Membangun kesadaran masyarakat akan pentingnya Green Construction mempunyai nilai minimum sebesar 3 dan maksimum sebesar 5, serta jumlah sebesar 100 dan rata-rata sebesar 3.85

\section{Pemilihan material atau bahan baku} yang ramah lingkungan mempunyai nilai minimum sebesar 2 dan maksimum sebesar 5, serta jumlah sebesar 98 dan rata-rata sebesar 3.77
Peraturan pemerintah dalam menerapkan Green Construction mempunyai nilai minimum sebesar 2 dan maksimum sebesar 4 , serta jumlah sebesar 84 dan rata-rata sebesar 3.23. [16], [17]

Pembuatan design yang efesien mempunyai nilai minimum sebesar 2 dan maksimum sebesar 4 , serta jumlah sebesar 77 dan rata-rata sebesar 2.96

Untuk grafik hasil keseluruhan analisa dari hambatan dalam penerapan Green Construction dengan pengolahan data menggunakan SPSS Statistics 26, dapat dilihat pada lampiran di gambar 3 .

\section{KESIMPULAN}

Dari hasil analisa dan pembahasan maka didapatkan kesimpulan bahwa dengan menggunakan metode kuesioner dan pengolahan dengan SPSS Statistics 26 maka didapatkan hasil pada proyek pembangunan TOD Mahata Margonda bisa dikatakan bahwa sudah menerapkan Green Construction walaupun ada sebagian faktor-faktor dari Green Construction yang belum diterapkan. Faktor kriteria Green Construction yang paling diterapkan atau mendominasi yaitu pada variabel limbah proyek dengan nilai rata-rata sebesar 3.748 dan yang paling rendah penerapannya yaitu variabel lapangan (site project) dengan rata-rata 3.198. Faktor tingkat kesulitan penerapan Green Construction yang paling mendominasi yaitu variabel penggunaan air dengan nilai rata-rata sebesar 3.283 dan yang paling rendah kesulitan penerapannya yaitu variabel energi dengan rata-rata 2.817. lalu pada faktor hambatan-hambatan dalam menerapkan Green Construction yang paling mendominasi yaitu faktor modal atau biaya dengan nilai rata-rata sebesar 4.00 dan yang paling rendah hambatan penerapannya yaitu variabel pembuatan 
design yang efesien dengan rata-rata 2.96

\section{DAFTAR PUSTAKA}

[1] J. F. Sinulingga, 2012. [Online]. Available: http://ejournal.uajy.ac.id/491/1/0MTS0157 8.pdf.

[2] R. P. Arviandi, 17 Februari 2019. [Online]. Available: https://medium.com/@rezaprama/ta ntangan- isu-infrastruktur-danlingkungan-hidup-di- indonesiamasa-depan-3a743da30fc.

[3] W. I. Ervianto, B. W. Soemardi, M. Abduh and S., "Pengembangan Model Assesment Green Construction Pada Proses Konstruksi untuk Proyek Konstruksi di Indonesia," Konferensi Nasional Pascasarjana Teknik Sipil (KNPTS), 2011.

[4] W. I. Ervianto, "Kendala Kontraktor dalam Menerapkan Green Construction Dalam Proyek Konstruksi Bangunan Gedung Di Indonesia," Seminar Nasional X2014, 2014

[5] T. E. Glavinich, Contractor's Guide to Green Building Construction, John Wiley, 2008.

[7] Rahmawati, R. A., \& Murdiyoto, R. A. (2021). Assessment On Transit Oriented Development Pondok Cina According to GBCI. Applied Research on Civil Engineering and Environment (ARCEE), 2(02), 7076.

[8] Nurwidyaningrum, D., Ulum, M., \& Syamsumarno, B. S. (2020). Investigation of Air Circulation For Indoor Air Quality Of Middle-Class Apartment in Jakarta, Indonesia. Applied Research on Civil
Engineering and Environment (ARCEE), 1(02), 16-21.

[9] Mungkasa, O. M. (2020). Green Infrastructure In Jakarta, Basic Understanding And Implementation Efforts In Indonesian Cities. Applied Research on Civil Engineering and Environment (ARCEE), 2(01), 2835.

[10] P. PP, This Is The Green Constructor Way, PT. PP, 2008.

[11] P. PP, Green Contractor Assessment Sheet, Jakarta: PT. PP, 2008.

[11] Sudjana, Metode Statistika, Bandung: Tarsito, 2005.

[12] Sugiyono, Metode Penelitian Kuantitatif, Kualitatif dan R\&D, Bandung: PT. Alfabet, 2016.

[13] I. Ghozali, Aplikasi Analisis Multivariate Dengan Program SPSS, Semarang: Badan Peneliti Universitas Diponegoro, 2001.

[14] Ervianto, W. I, 2015 Implementasi Green Construction sebagai Upaya Mencapai Pembangunan Berkelanjutan di Indonesia. Konsferensi Nasional Forum Wahana Teknik ke II.

[15] Ervianto, W. I. (2012). Selamatkan Bumi Melalui Konstruksi Hijau. Yogyakarta: Andi.

[16] Griffin, C. T., Knowles, C., Theodoropoulus, C., \& Allen, J. H, 2012. Barriers to the Implementation of the Structural Material In Green Building. Portland, Oregon, United State: Portland State University.

[17] Sudiartha, K. E., Nadiasa, M., \& Jaya, I. M, 2014. Kajian FaktorFaktor Green Construction Pada Proyek Konstruksi Gedung Di Kabupaten Badung. 148-155. 


\section{Lampiran}

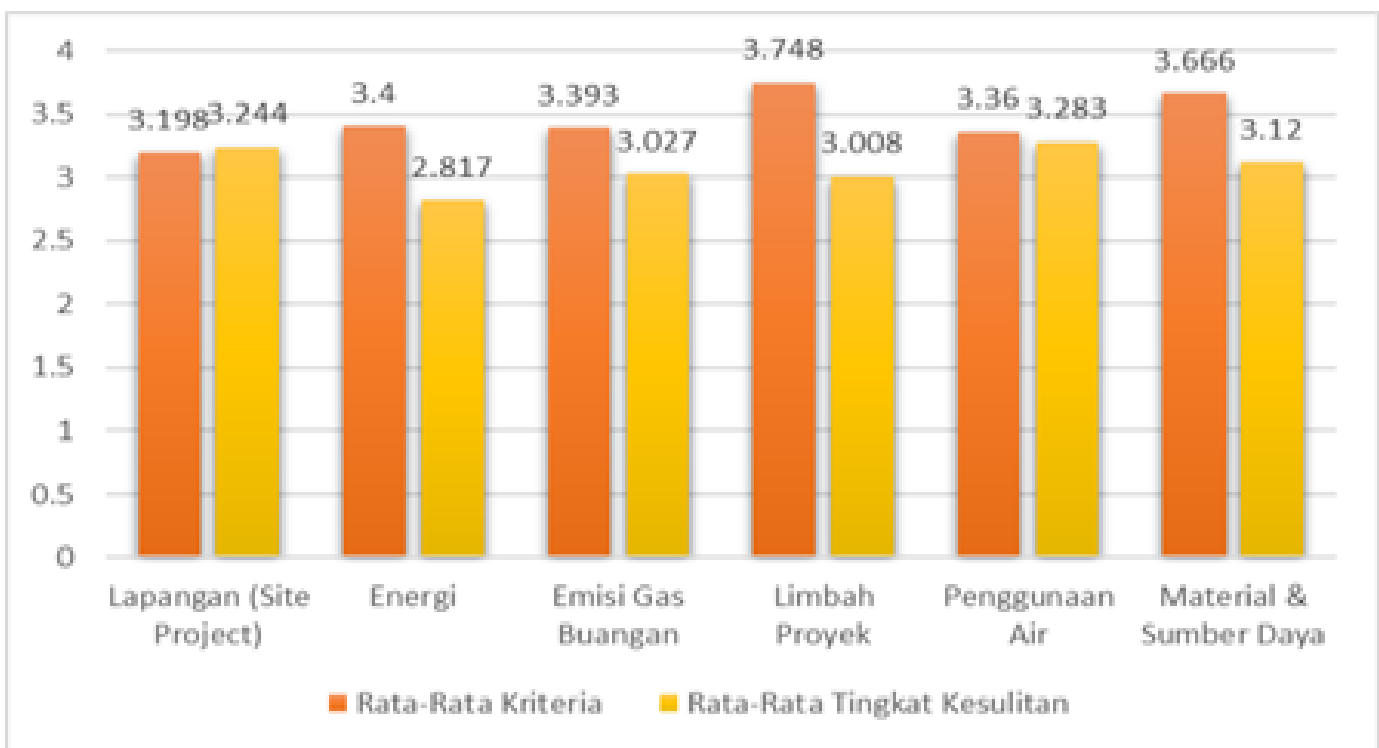

Gambar 2. Grafik Tingkat Kriteria dan Tingkat Kesulitan Green Construction

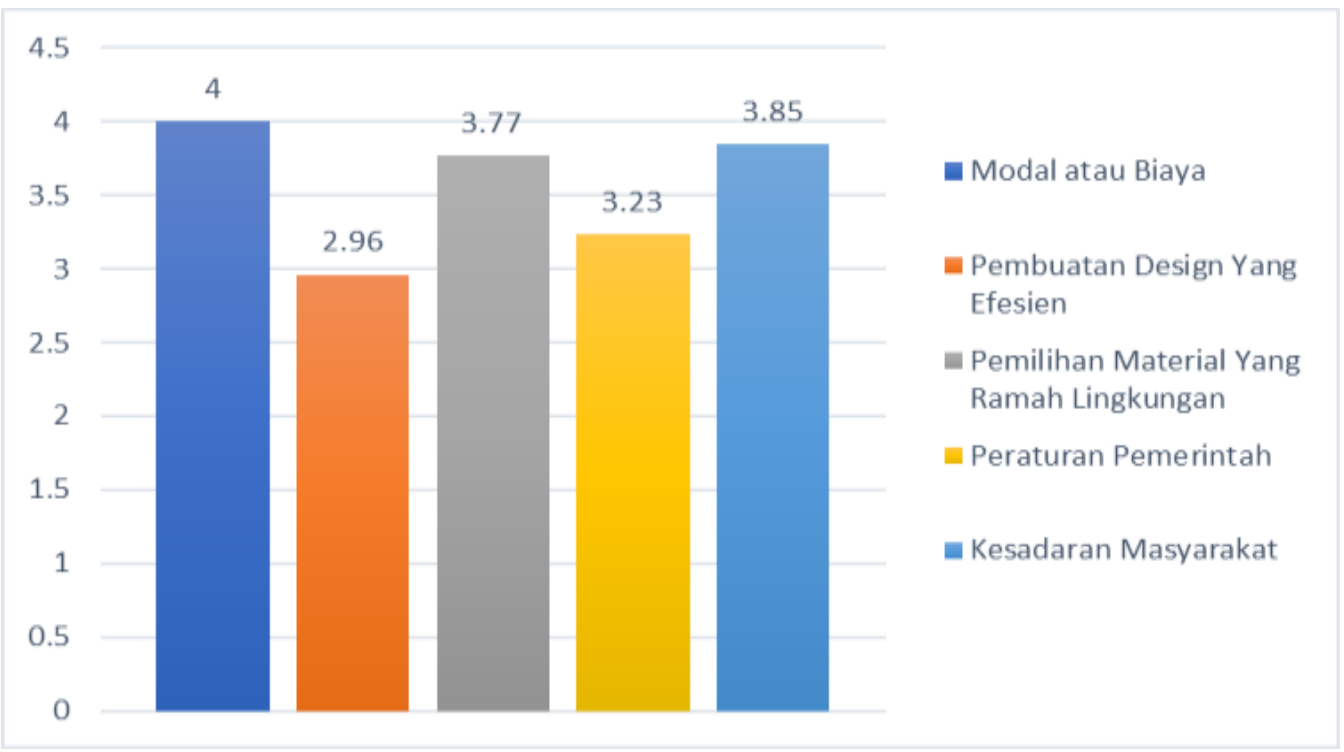

Gambar 3. Grafik Hambatan Penerapan Green Construction 